\title{
Demodulation of Vibration Signal Based on Envelope-Kurtogram for Ball Bearing Fault Detection
}

\author{
Berli Kamiel \\ Department of Mechanical Engineering, Universitas Muhammadiyah Yogyakarta \\ Kampus Terpadu UMY Jalan Brawijaya, Yogyakarta, Indonesia \\ $+62274387656 /+62274387646$ \\ e-mail: berlikamiel@umy.ac.id
}

\begin{abstract}
Abstrak
Bantalan gelinding adalah komponen mesin yang kerap mengalami kerusakan akibat kondisi operasi dan lingkungan yang berat. Metode yang umum digunakan dalam mendeteksi kerusakan/cacat pada sebuah bantalan adalah analysis envelope. Namun metode ini membutuhkan pengaturan frekwensi sentral dan bandwidth yang tepat - yang berkaitan dengan frekwensi resonansi bantalan- agar demodulasi sinyal berjalan efektif. Penelitian ini mengusulkan kurtogram untuk menentukan frekwensi sentral dan bandwidth yang tepat sehingga didapatkan bentang frekwensi dengan kandungan impuls paling tinggi atau nilai kurtosis tertinggi. Analysis envelope diterapkan pada sinyal getaran yang telah di filter menggunakan parameter frekwensi sentral dan bandwidth yang diperoleh dari kurtogram. Hasil penelitian menunjukkan bahwa metode envelope-kurtogram efektif untuk mendeteksi cacat pada sebuah bantalan seperti ditunjukkan pada spektrum envelope dimana puncak (peaks) berhimpit dengan frekwensi karakteristik cacat bantalan (BPFO) dengan akurasi yang tinggi. Demikian pula dapat diamati dengan jelas beberapa harmonik BPFO yang memberikan informasi tingkat kerusakan yang terjadi pada bantalan.
\end{abstract}

Kata kunci: Kurtogram; analisis envelope; demodulasi; frekwensi sentral; bandwidth

\begin{abstract}
Rolling element bearings often suffer damage due to harsh operating and environmental conditions. The method commonly used in detecting faults in a bearing is envelope analysis. However, this method requires setting the central frequency and the correct bandwidth - which corresponds to the resonance frequency of the bearing - for signal demodulation to be effective. This study proposes a kurtogram to determine the correct central frequency and bandwidth to obtain the frequency band with the highest impulse content or the highest kurtosis value. Analysis envelope is applied to the filtered vibration signal using the central frequency and bandwidth parameters obtained from the kurtogram. The results showed that the envelope-kurtogram method is effective for faulty bearing detection as shown in the envelope spectrum where the peaks coincide with the bearing defect characteristic frequency (BPFO) with high accuracy. Likewise, it can be observed several BPFO harmonics which provide information on the level of bearing fault.
\end{abstract}

Keywords: Kurtogram; envelope analysis; demodulation; central frequency; bandwidth

\section{INTRODUCTION}

Rolling element bearings are one of the most important mechanical components in rotary machines and often suffer damage due to harsh working conditions. Damage to bearings has a direct effect on the engine performance which can disrupt the overall production process. Therefore it is necessary to monitor the condition of the bearings to ensure that the bearings are always in good condition. Bearing condition diagnosis consists 
of several steps aimed at extracting bearing characteristics from a signal [1]. Although there are many types of signals, vibration signals are the most widely used signals because they are non-invasive, real-time, and do not interfere with machine work when sampling the signal [2].

Detection of bearing fault is generally based on the characteristics of the vibration signal in the form of the time domain or frequency domain. In the case of a local fault in the innerrace or outer-race bearing, several impulse sequences are generated when the rolling element crosses the local fault. The sequence of impulses is periodic which characteristics vary with the bearing geometry. Likewise, impulses produce resonance in the bearings and the overall machine structure [3]. A bearing local fault produces a sharp array of impulses over a wide bandwidth. The vibration signal generated by the faulty bearing is generally nonstationary, that is, a signal whose statistical value varies with time [4]. Signals with these characteristics are often called cyclostationary or pseudocyclostationary.

Envelope analysis is a method that has been used widely for the detection of bearing fault based on high-frequency resonance demodulation as has been investigated by $[5,6]$. Envelope analysis performs signal filtering over certain ranges of frequencies; in general, the frequencies around resonance are followed by demodulation. The resulting signal demodulation is then transformed into an envelope spectrum where the periodic components associated with bearing component defects can be identified. In general, the spectrum obtained directly from the raw signal is not effective in detecting bearing defects, especially during early faults [7]. Fourier transforms and Hilbert transforms subsequently are used to obtain the envelope spectrum.

The main difficulty in implementing envelope analysis is determining the center frequency and bandwidth ( $f, B w$ ) of the frequency bands that contain the impulse frequencies generated by bearing fault [8]. In practice, the frequency band is determined based on previous experience. However, this stage is often neglected in some cases, which consequently affects the accuracy of bearing fault detection.

Considering this problem, this study proposes a kurtogram to select the frequency band that has the largest kurtosis value or the largest signal-to-noise ratio (SNR) value. The kurtogram shows kurtosis results for a range of window lengths and frequencies. A high kurtosis level corresponds to a high level of nonstationary or non-Gaussian behavior which relates to vibration signal generated by faulty bearings. After the frequency band with the largest kurtosis value is obtained, then a bandpass filter is applied to the raw vibration signal to obtain the signal with the most impulsive content for envelope analysis.

\section{MethodS}

\subsection{Kurtogram}

The rolling bearing fault produces high-frequency resonances in the rotating machine, which can produce modulations at the characteristic frequency of the bearing. As a result, for bearing fault detection based on envelope analysis, characteristic frequency components should be demodulated using an optimal center frequency and bandwidth ( $f, B W$ ) selection. In this sense, spectral kurtosis-based algorithms like kurtogram attempts to find this combination in a computationally efficient manner [9]. Kurtogram plots the spectral kurtosis values as a function of frequency and windows length, which define the spectral resolution. The kurtosis value for each frequency $(f)$ of a signal $x(t)$, i.e. spectral kurtosis, can be calculated using STFT $(X(t, f))$ such that

$$
S K=\frac{X^{4}(t, f)}{\left\langle X^{2}(t, f)\right\rangle^{2}}-2
$$

where $X(t, f)$ is the envelope as a function of time-frequency; $X^{2}(t, f)$ is the power spectrum for each time $(t)$; and the average of all these power spectral values $\left\langle X^{2}(t, f)\right\rangle^{2}$ corresponds to the power spectrum of the analyzed signal as a whole. In this context, spectral kurtosis 
can be considered as a fiter such that the frequency bands containing impulsive signals have a maximum value and zero for that frequency bands consisting of stationary signals.

\subsection{Envelope Analysis}

Bearing fault vibration signal always occurs in the form of modulation where the envelope analysis techniques have been proven effective to extract the periodical impact in the vibration signal. The process of extracting impact includes bandpass filtering on the signal to reveal the fault character and subsequently envelope analysis rearrange the fault frequency in the low frequency [10]. Several transformation methods have been proposed to extract the envelope signal. In this study, the envelope analysis based on Hilbert transform is adopted. The Hilbert transform for a signal $x(t)$ is defined as

$$
\tilde{x}(t)=\frac{1}{\pi} \int_{-\infty}^{+\propto} \frac{x(\tau)}{t-\tau} d \tau
$$

therefore analytic signal of $x(t)$ can be written as

$$
z(t)=x(t)+j \tilde{x}(t)
$$

and in complex form

$$
z(t)=a(t) \exp (j \omega(t))
$$

where $a(t)$ is the envelope signal, by calculating the Fourier transform, the envelope spectrum of $x(t)$ is obtained. If the bearing has a fault, the fault characteristic frequency can be observed in the envelope spectrum.

\subsection{Experimental Setup}

Local fault in the bearing produces a frequency characteristic that is proportional to the frequency of the shaft. Bearing defects can occur in the inner race, outer race, ball element, and cage element. In this study, the outer race fault on the bearing was made using the wire cut technique with a wire diameter $0,5 \mathrm{~mm}$. The fault characteristic frequency related to the outer race fault, Ball Pass Frequency Outer Race (BPFO), can be expressed as follow

$$
B P F O=\frac{N b}{2} \times f_{r} \times\left(1-\frac{B d}{P d} \times \cos \alpha\right)
$$

where $N_{b}$ corresponds to number of ball, $f_{r}$ is shaft speed (RPM), $B_{d}$ is ball diameter $(\mathrm{mm})$, $P_{d}$ is pitch diameter $(\mathrm{mm})$ dan $\alpha$ is contact angle.

This study uses a test rig designed to simulate the vibration of normal bearings and faulty bearings using double row self-aligned ball bearings of the SKF 1207 EKTN9. Bearing sizes are depicted in Table 2.1 while the schematic of the test equipment is shown in Figure 2.1 which consists of a shaft with a length of $1 \mathrm{~m}$, a diameter of $30 \mathrm{~mm}$, and supported by two bearings. The test bearing with defects in the outer race is located on the far side of the electric motor while the other bearings on the near side are normal (no-fault). The faulty bearing shown in Figure 2.2 is made by scraping the outer race using an EDM machine with a width and depth of $0,5 \mathrm{~mm}$ and $1,5 \mathrm{~mm}$, respectively. A disc-shaped load of $1 \mathrm{~kg}$ is mounted on the middle of the shaft. The 1,5 HP electric motor drives the shaft via a fixedclutch coupling mechanism at a speed of 936 RPM $(15,6 \mathrm{~Hz})$. Furthermore, the bearing defect frequency is calculated using Equation 1 and gives BPFO $=98,5 \mathrm{~Hz}$ 
Table 2.1 Size of bearing element SKF 1207 EKTN9

\begin{tabular}{lc}
\hline Bearing elements & Dimension \\
\hline Ball diameter $(\mathrm{Bd})$ & $8,5 \mathrm{~mm}$ \\
Pitch diameter $(\mathrm{Pd})$ & $53,95 \mathrm{~mm}$ \\
Outer diameter & $72 \mathrm{~mm}$ \\
Inner diameter & $35 \mathrm{~mm}$ \\
Number of ball $(\mathrm{Nb})$ & 30 \\
Contact angle $(\alpha)$ & $0^{\circ}$ \\
\hline
\end{tabular}

The vibration signal in the radial direction is recorded using a Bruel \& Kjaer accelerometer mounted on the test bearing housing. The accelerometer is connected to the input side of the NI 9234 data acquisition system from National Instrument which output side is connected to a PC. The sampling rate is set at a relatively high rate of $51200 \mathrm{~Hz}$ so that it can record high-frequency impulses for a very short duration.

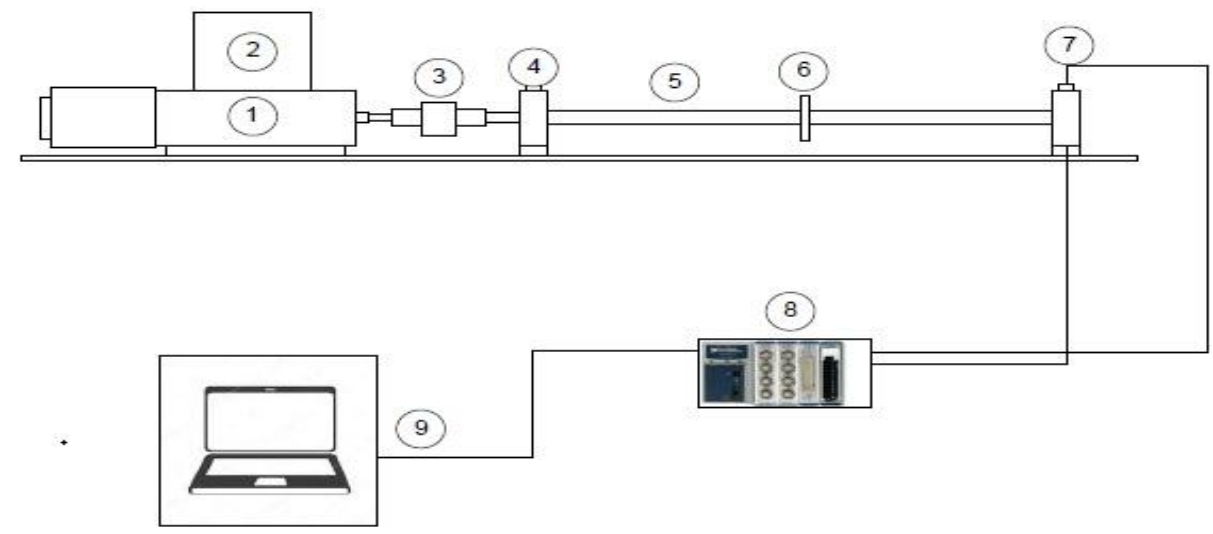

Figure 2.1 Schematic diagram of the test rig.1) electric motor, 2) inverter, 3) clutch, 4) bearing housing, 5) shaft, 6) disc weight, 7) accelerometer, 8) DAQ system, 9) PC

The proposed identification procedure of the faulty bearing is shown in Figure 2.3 which begins by calculating the local kurtosis value of the faulty bearing raw vibration signal at various frequency bands using a fast kurtogram algorithm. The calculation result is used to select the most impulsive frequency band and the obtained center frequency and bandwidth parameters are used to set the parameter of the filter band. Subsequently, it is used to filter the raw vibration signal of the faulty bearing and is followed by the envelope demodulation procedure. The signal is then transformed into a spectrum using the FFT algorithm and the bearing fault identification process is carried out by comparing the calculated bearing fault frequencies with the peaks on the spectrum corresponding to the bearing fault frequencies. 


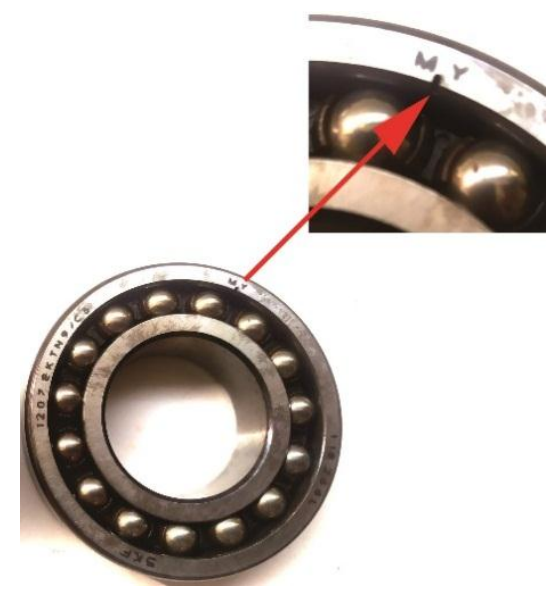

Figure 2.2 Outer race fault

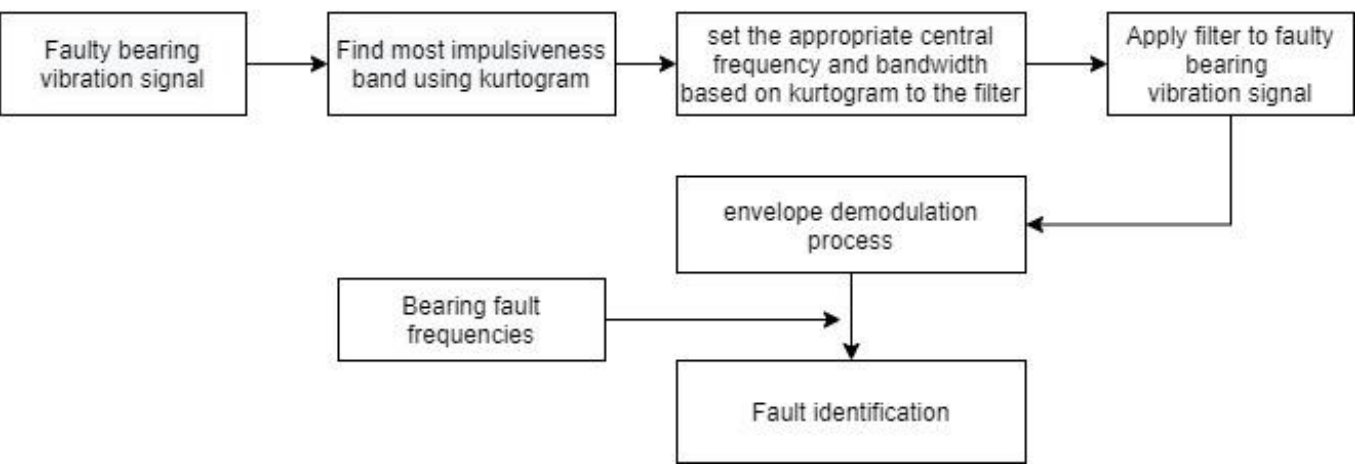

Figure 2.3. Identification framework

\section{RESULTS AND DISCUSSION}

Figure 3.1 shows the waveform of the bearing vibration signal with the outer race fault. It shows that the waveform contains plenty of noise although the impact is visible. It is observed that the waveform is modulated at a certain frequency where the main modulation frequency is around $1 / 0,011 \mathrm{~Hz} \cong 90,9 \mathrm{~Hz}$. From Equation 1, the ball pass frequency outer race, BPFO is $98,5 \mathrm{~Hz}$ hence it is obvious that the waveform is from a bearing with outer race fault. The power spectrum of the signal shown in Figure 3.2 indicates that the clear peaks at BPFO and its harmonics are not visible. The outer race fault characteristic frequency is inherently difficult to extract because of the heavy noise thus the spectrum of raw vibration signal does not give a useful diagnosis for bearing fault condition. 


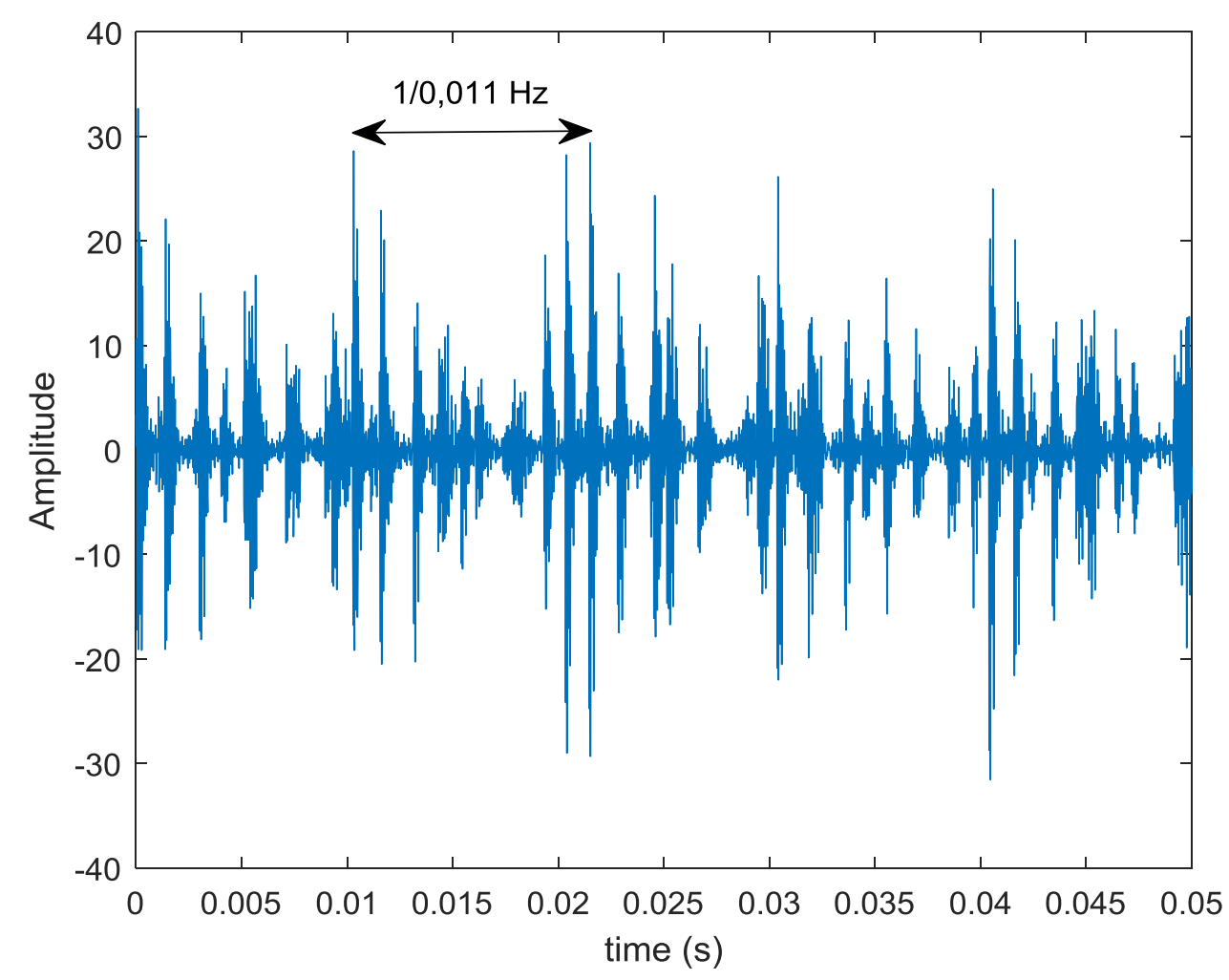

Figure 3.1. Time waveform of faulty bearing

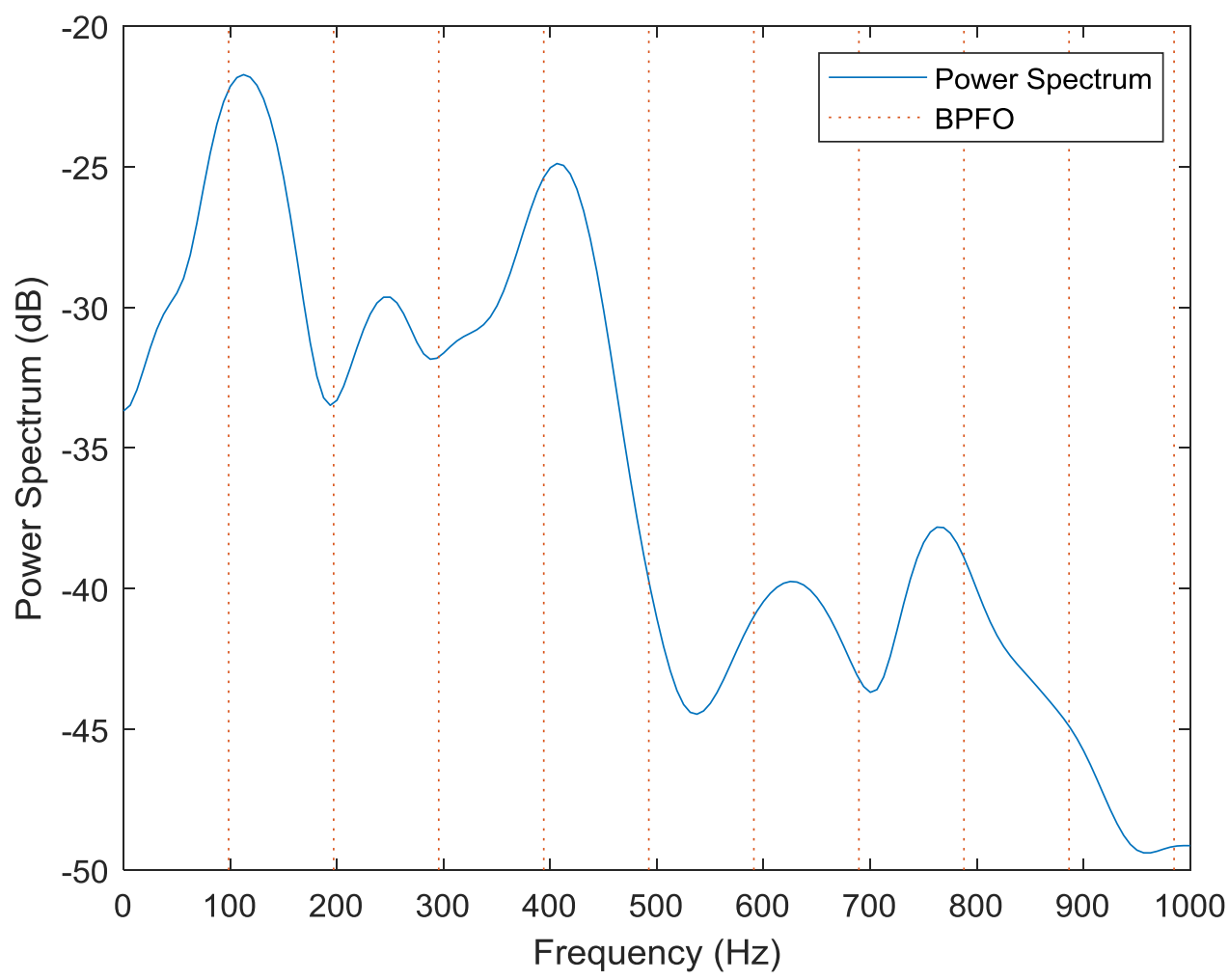

Figure 3.2 Power spectrum of faulty bearing 
From the kurtogram of the bearing fault signal depicted in Figure 3.3, it can be seen that the bearing resonance frequency band is at the circled area which has the highest kurtosis value. The band has the central frequency, $f=21,3 \mathrm{kHz}$, bandwidth, $\mathrm{BW}=8,5 \mathrm{kHz}$ and kurtosis, $\mathrm{K}=6,6$. The selected area indicates the most impulsive signal where bearing resonance occurs during impact between rolling elements and local fault. The Kurtogram was calculated using the Fast Kurtogram algorithm proposed by Antoni [11].

A bandpass filter with central frequency and bandwidth obtained from the kurtogram then can be applied to the raw vibration signal to extract the more impulsive signal for envelope spectrum analysis. The filter only allows the raw vibration signal with a frequency between $f-B W / 2$ to $f+B W / 2$ to pass and subsequently, the envelope analysis is performed. This step ensures that only the selected frequency band transforms to the envelope spectrum. Since the transformation is only carried out to the most impulsive signal frequency band so it reveals sharp and high peaks that correspond to faulty bearings characteristic frequency.

The result of the envelope spectrum of the filtered signal is shown in Figure 3.4. It is shown that by bandpass filtering the raw vibration signal based on the frequency band suggested by Kurtogram, the envelope spectrum can reveal a fault frequency of $98,5 \mathrm{~Hz}$ and its harmonics. One can find that 1xBPFO has the highest peak which makes fault detection is easy. The harmonics of BPFO are also obvious where the series of BPFO's harmonics from $2 x$ to $9 x$ are in general have high peaks and visible. It shows that some noise has been reduced and the impact signatures have been enhanced. The number of harmonics series may indicate the level of severity and noise therefore with 9 harmonics it may conclude that the bearing is severely damaged and its vibration signature is covered with heavy noise. However, the envelope spectrum shows a relatively low noise floor with some unidentified peaks, which means that the raw vibration signal was effectively bandpass-filtered using a filter with central frequency and bandwidth obtained from kurtogram.

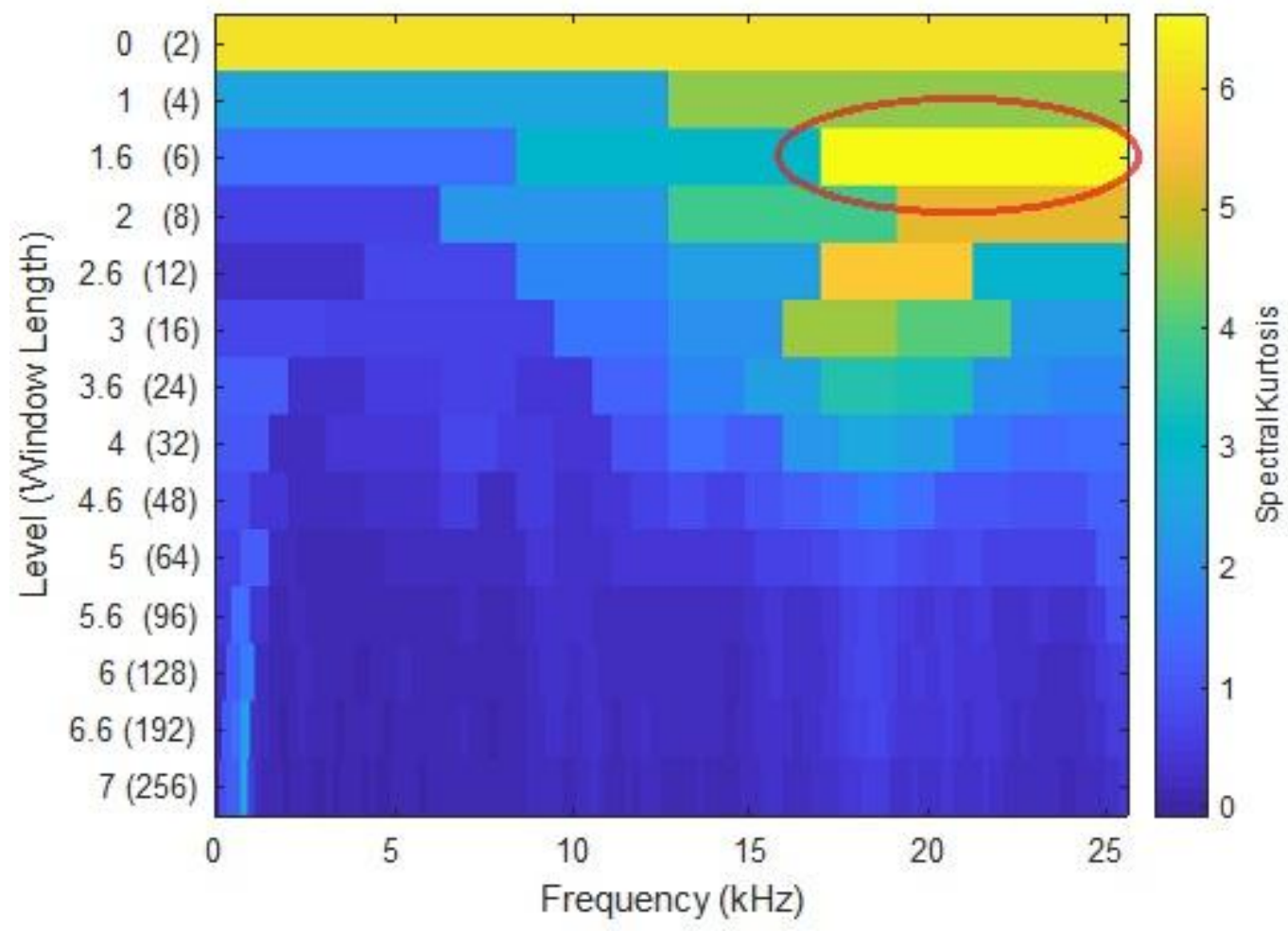

Figure 3.3. Kurtogram of outer race fault signal 


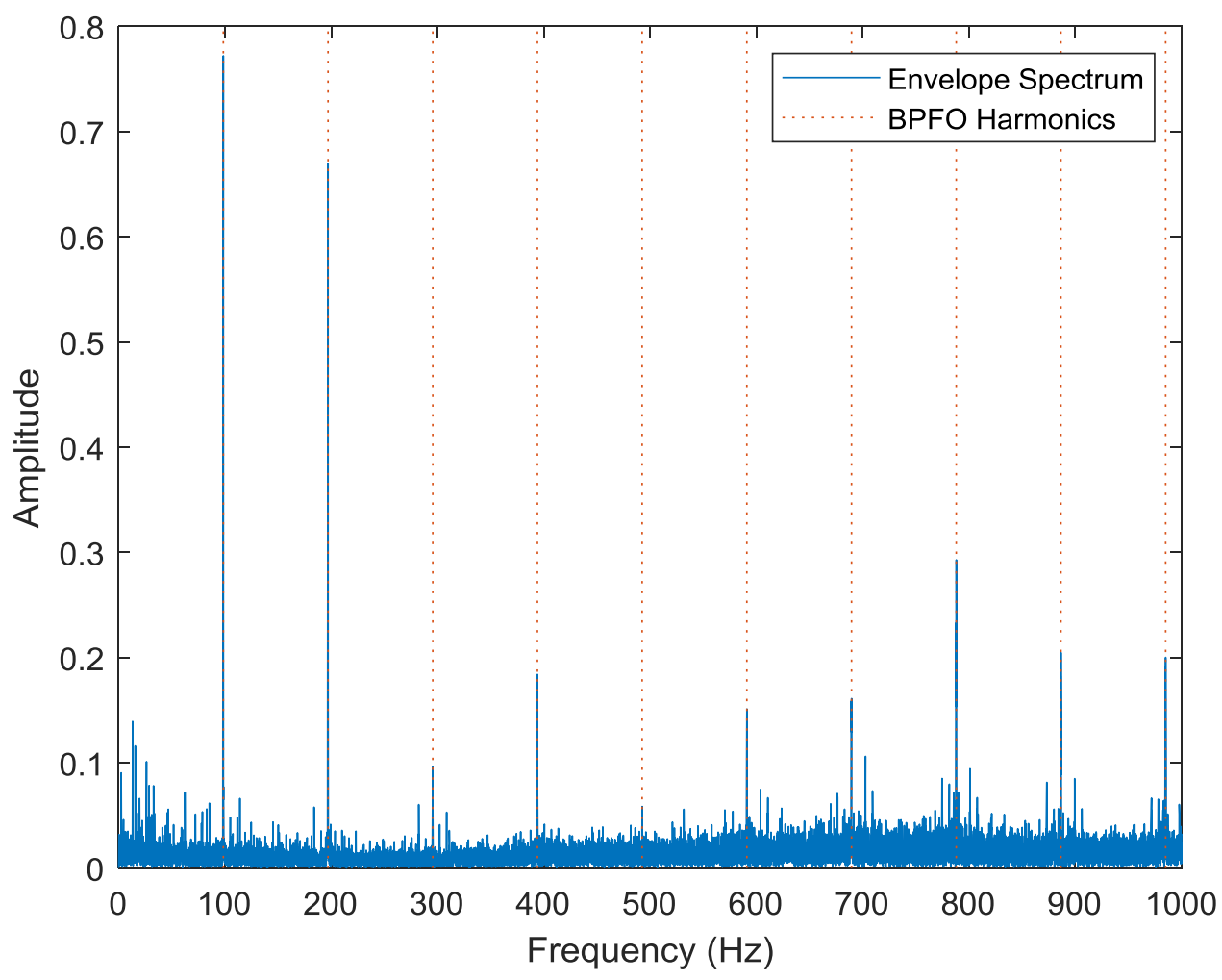

Figure 3.4 Envelope spectrum of the filtered signal

\section{CONCLUSION}

This paper proposes an envelope analysis-based kurtogram of bearing fault detection. With the help of kurtogram, the most impulsiveness frequency band of the raw vibration signal and its corresponding central frequency and bandwidth can be determined. The selected central frequency and bandwidth are effectively applied to the signal filtering process therefore the filtered signal is ready for envelope analysis. The results show that the envelope spectrum reveals the characteristic frequency of the outer race-bearing fault with high accuracy. The peak corresponding to the fault frequency exactly coincides with BPFO and the peak is relatively taller than the surrounding peaks which make the fault detection process is effective. It can be noticed that the several BPFO harmonics are also clearly visible which gives additional information about the severity level of the bearing.

\section{REFERENCES}

[1] Du W, Wang Z, Gong X, Wang L, Luo G. Optimum IMFs Selection Based Envelope Analysis of Bearing Fault Diagnosis in Plunger Pump. Shock and Vibration. 2016;2016:1248626.

[2] Qiu M, Li W, Zhu Z, Jiang F, Zhou G. Fault Diagnosis of Bearings with Adjusted Vibration Spectrum Images. Shock and Vibration. 2018;2018:6981760.

[3] Wen-Chang T, Yi-Fan L, Min-Chun P, Resonant-frequency band choice for bearing fault diagnosis based on EMD and envelope analysis. 2010 8th World Congress on Intelligent Control and Automation; 2010 7-9 July 2010.

[4] Zhang $X$, Kang J, Zhao J, Zhao J, Teng $\mathrm{H}$. Rolling element bearings fault diagnosis based on correlated kurtosis kurtogram. Journal of Vibroengineering. 2015;17(6):302334. 
[5] Kim S, An D, Choi J-H. Diagnostics 101: A Tutorial for Fault Diagnostics of Rolling Element Bearing Using Envelope Analysis in MATLAB. Applied Sciences. 2020;10(20):7302.

[6] Duan J, Shi T, Zhou H, Xuan J, Zhang Y. Multiband Envelope Spectra Extraction for Fault Diagnosis of Rolling Element Bearings. Sensors (Basel, Switzerland). 2018;18(5):1466.

[7] Senanayaka JSL, Khang HV, Robbersmyr KG, Towards online bearing fault detection using envelope analysis of vibration signal and decision tree classification algorithm. 2017 20th International Conference on Electrical Machines and Systems (ICEMS); 2017 11-14 Aug. 2017.

[8] Xu L, Chatterton S, Pennacchi P. A Novel Method of Frequency Band Selection for Squared Envelope Analysis for Fault Diagnosing of Rolling Element Bearings in a Locomotive Powertrain. Sensors (Basel, Switzerland). 2018;18(12):4344.

[9] Antoni J, Randall RB. The spectral kurtosis: application to the vibratory surveillance and diagnostics of rotating machines. Mechanical Systems and Signal Processing. 2006;20(2):308-31.

[10] Sui W, Zhang D, Research on envelope analysis for bearings fault detection. 2010 5th International Conference on Computer Science \& Education; 2010 24-27 Aug. 2010.

[11] Antoni J. Fast computation of the kurtogram for the detection of transient faults. Mechanical Systems and Signal Processing. 2007;21(1):108-24. 